\title{
Considering Culture in Designing Web Based E-commerce
}

\author{
Dr. Kyeong Kang \\ Faculty of Engineering and Information Technolohy \\ University of Technology Sydney Australia
}

\section{Introduction}

E-commerce is design for users in different physical locations, and web based e-commerce sites intend to attract users from international as well as local regions (Callahan, 2008; Chen et al., 2004). There are increasing numbers of e-commerce sites that provide links to different country sites, however most of the sites are in English and not all sites provide languages other than English for web users from different countries (Internetworldstats, 2007). It has also been found in earlier studies, that the presentation of information through different languages and web design elements such as navigation, images and color can provide diverse reactions from people in different cultures (Kang \& Corbitt, 2002; Nguyen et al., 2006). Usually, presentation of business information and services offered through the web is not only conveyed with designers' ideas but are also possible with web users' perception of choices. In short, information on the web relies on both groups - designers and users, forming a common perception. In a global context, many web interfaces do not support effective usage due to application of unsuitable tools for conveying information in a global context, since most of the information is presented on the web by icons, metaphors, shapes, colors of text and background, frame/ text locations on screen, etc., which, may be relevant to some culture groups but may be misinterpreted by the global audience.

E-commerce businesses are targeting business expansion into other countries, and to facilitate this, international users need to get appropriate support through web design features to use the site as an active business platform (Kang \& Corbitt, 2002; Nguyen et al., 2006). Also providing appropriate language for international users on the site is important, not only just translation, but also delivering information in a local nous (Ford \& Gelderblm, 2003; Piller, 2003).

This chapter presents investigation of global e-commerce sites, describing methods for understanding cultural issues in designing web based e-commerce sites. The author attempted to show how culture affected the features of the sites, and how these features might be adapted other cultures, through examples presented in the chapter. The chapter focuses on popular design features in web interfaces of global e-commerce sites and differences arising from design in different country sites. 


\section{Understanding Users and Culture}

In recent years, e-commerce has made it possible for users to feel connected and have closer contacts, in turn impacting on the mode of commercial transactions (Chen et al., 2004; Horton, 2006; Statistics, 2007). Therefore cultural boundaries are of lesser importance in business, and the market place is not dependant on the physical store alone (Chen et al., 2004; Sudweeks \& Ess, 1998). Products and services can be easily presented through the ecommerce, and business transactions are easy to carry out in the Business to Consumer (B2C) setting. This phenomenon has changed the cultural boundaries. Nevertheless, without a clear understanding of cultural differences as applied to e-commerce, specifically web interface design, the potential of e-commerce is difficult to realise (Ford \& Gelderblm, 2003; Horton, 2006; Zhang, 2000). To improve this, interface design of web based e-commerce sites for a global context needs to have an emphasis on an enhanced cultural context for the interface (del Galdo \& Nielsen, 1996; Kang \& Corbitt, 2002). Consequently study of a usable web interface design for different culture background users and designers is being acknowledged as an important aspect of e-commerce.

In e-commerce, culture has a strong influence on the customers' (or users') responses, feeling and trust or satisfaction (Chau et al., 2002; Rose et al., 2003). Users feel and act on web sites within the culture. Users' negative or positive react to e-commerce web sites and they are being understood and identified in the e-commerce practice. In Chau et al's (2002) study on user behaviour in relation to culture in e-commerce, it was argue that e-commerce users are different in nature as they are surrounded by different cultures, and the emphasis on local user preferences. This is the key issue to support e-commerce practices. Even though the Chau et al's study has not fully investigated users' responses from the same ecommerce web site in different cultures, it shows user responses in e-commerce sites and important implications in improving user responses. Rose et al (2003) also emphasised that culture has a major impact on user responses to e-commerce sites. Rose et al's (2003) study shows that, users understanding of information on the web will be different to users from different cultures. Therefore presenting information on e-commerce sites can be an essential issue for users and providers. Barber and Badre's (2000) study about merging culture and usability work is a helpful guideline for attracting potential international users (Barber \&

Badre, 2000).

Considering culture in presenting colour on the screen is that it has different psychological and social associations in different cultures (Badre, 2002; Nielsen, 2000). Barber and Badre's (2000) study shows that various user interpretations of icons and graphical components, colours, fonts, shapes, icons and metaphors, geography, language, flags and sounds directly affects the user interaction with a site. More importantly, different users have different concepts of screen usage. Del Galdo and Nielsen (1997) for example have demonstrated that the right-to left writing direction of the Arabic language is the common way of design of screens in Arabic countries and users start reading from the top right-hand to the bottom left-hand side even in English language (del Galdo \& Nielsen, 1996). Therefore culture influences certain methods of performing tasks, even common everyday jobs in certain ways (Fernandes, 1995). Design practices result from life long training of humans and set rules and circumstances. History and values can also impact on a web site user's perception. Hence, cultural understanding deals with how differences between people from different culture impact on their behaviour in particular circumstances, as in web based e-commerce. Users in different cultures portray different meanings to web based e-commerce interface 
elements in usage (del Galdo \& Nielsen, 1996; Fernandes, 1995). The challenge of web interface design for e-commerce is to create a good design for the target users based in different cultural contexts. Therefore it is necessary to study web design practices focusing on target users and interface design issues by considering practices used by designers for the provision of a platform for web based B2C e-commerce. This can be done by providing either a single global site designed for users from all cultural backgrounds, or separate local sites for users from specific nations or cultures. Many researchers have proposed web interface design for e-commerce through distinct approaches for global and local users to provide effective user interaction. They have suggested changes for improving user activities to improve effectiveness in e-commerce (Kim \& Moon, 1998; Nielsen, 2000; Shneiderman, 2000). However, there are no holistic studies examining the designers' approaches in different cultures.

\section{E-commerce Type and Business Model}

The intention of creating web based e-commerce is that, business can significantly reduce its operating costs, expand market without geographical restrictions, provide global exposure to the business, deliver effective customer services remotely, and increase overall product value (Afuah \& Tucci, 2003; Elliot \& Keen, 2002). In this way, the web based e-commerce model enables small to medium business to compete with a larger business on an even playing field; sometimes even providing advantages to the smaller business because it usually has lower cost structures and is more agile (Elliot \& Keen, 2002). Table 1 presents a brief description of business models and identifies B2C and B2B business models that are relevant in the current e-commerce environment.

\begin{tabular}{|l|l|l|}
\hline Business model & Description & $\begin{array}{l}\text { E-commerce } \\
\text { type }\end{array}$ \\
\hline e-shops & $\begin{array}{l}\text { Selling of products and services over the e- } \\
\text { commerce sites }\end{array}$ & B2C \\
\hline e-malls & $\begin{array}{l}\text { Incorporates utilises that enables individual } \\
\text { transaction processes under a single name, and } \\
\text { consists of a collection of e-shops }\end{array}$ & B2C \\
\hline e-procurements & $\begin{array}{l}\text { Electronic tendering and procurement of } \\
\text { goods and services from suppliers where a } \\
\text { dedicated procurement system exist that is } \\
\text { share with suppliers and e-commerce business }\end{array}$ & B2B \\
\hline e-auctions & $\begin{array}{l}\text { Intermediary services being provided to } \\
\text { buyers and sellers who use the services to }\end{array}$ & B2C \\
\hline
\end{tabular}




\begin{tabular}{|l|l|l|}
\hline & $\begin{array}{l}\text { trade in an auction format. Invoicing is } \\
\text { provided by the e-auction business and } \\
\text { processes to resolve dispute are also provided } \\
\text { through the web }\end{array}$ & | \\
\hline virtual communities & $\begin{array}{l}\text { Contribute additional value in e-commerce } \\
\text { site, and raise feedback from community } \\
\text { members }\end{array}$ & B2C \\
\hline $\begin{array}{l}\text { collaboration } \\
\text { platforms }\end{array}$ & $\begin{array}{l}\text { Collaboration between enterprises through a } \\
\text { set of tools }\end{array}$ & B2C \\
\hline $\begin{array}{l}\text { third-party } \\
\text { marketplaces }\end{array}$ & $\begin{array}{l}\text { Represents creation of a market through } \\
\text { customers' requests and response by suppliers }\end{array}$ & B2C \\
\hline $\begin{array}{l}\text { value-chain } \\
\text { integrators }\end{array}$ & $\begin{array}{l}\text { Represents a function of a particular business } \\
\text { within the value chain, such as payment and } \\
\text { management services }\end{array}$ & B2B \\
\hline $\begin{array}{l}\text { value-chain service } \\
\text { providers }\end{array}$ & $\begin{array}{l}\text { Specialise on a specific function for the value } \\
\text { chain }\end{array}$ & B2B \\
\hline $\begin{array}{l}\text { information } \\
\text { brokerage \& trust } \\
\text { services }\end{array}$ & $\begin{array}{l}\text { Use open networks to provide the huge } \\
\text { amount of data from integrated business } \\
\text { operations }\end{array}$ & B2B \\
\hline
\end{tabular}

Table 1. Description of business models and e-commerce based on Timmers' model (1998, 2000)

The business models broadly cover e-shops, e-procurement, e-malls, e-auctions, virtual communities, collaboration platforms, third-party marketplaces, value chain integrators, value-chain service providers, information brokerage and trust services (Timmers, 1998, 2000). These models broadly cover all business functions in e-commerce implemented on the web but not necessarily only for web based B2C e-commerce. As in any business, the models listed above can be present in a B2C web site depending on its business goals. Elliot and Keen (2002) refined the broad ten categories for simplicity into four primary business models, which are e-shops, e-malls, value-chain service provider and third-party market place (Elliot \& Keen, 2002).

From the author's point of view, B2C business models can solely be represented as e-shops, e-procurements, e-malls, e-auctions, virtual communities, collaboration platforms and third party market places out of the ten models described by Timmers (1998 and 2000). For example, Airline industries are truly global due to the nature of their business and they have so far utilised web design and technology to promote their business to an international market quite actively. Therefore, airline sites are suitable for investigating how web design feature are used for facilitating business in a global market. Further, according to Timmers' (1998 and 2000) e-commerce business model 'e-shops', retailers replace their physical stores entirely with online operations (Timmers, 1998, 2000). Airline businesses aspire to have a similar business model where customers can directly do business online or use travel agents who perform transactions online. If travel agents are also considered as customers of airline 
businesses, then including direct customers, all customer access and the pertinent business information is delivered to customers without prominent physical shopfronts. Therefore, airline global sites are selected as an example of global business as airlines come closest to one of Timmers' (1998 and 2000) e-commerce models.

\section{Research Approach}

As the literature review describes in Section 2, there are important issues in web design of ecommerce that are not clearly understood by the e-commerce community to effectively use global web based e-commerce. For supporting interactive web sites in e-commerce, the user's trust in using web sites for conducting business and designer's attitudes in supporting services provided by a business. Also cultural issues impacting on design of successful ecommerce sites were found to be issues relevant to the research community (Gefen \& Devine, 2001; Kim \& Moon, 1998). This research was through observations of design features in global e-commerce sites, analysing design features and the reasons for it.

As Yin (1994) suggested, evidence of case studies may come from six sources such as documents, archival records, interviews, direct observation, participant observation and physical artifacts (Yin, 1994). In this example, observations and documents were used in the process of conducting the case study. Firstly, the author focused on design features and information presentation differences in large global corporation web sites. Understanding how color, image presentations and facilities for data entry in different sites, and how the page included different regions. The author also considered complexity of a page including text density, site structure, frame and global links. This approach sought to confirm the generalizations and to test the impact of cultural differences on web design. This exploratory investigation attempted to formulate more precise objectives for further researching the problem.

Firstly, the author selected airline sites based on Timmers' business model (in section 3), and identified information web design styles; page layout, visual design elements and language options. Secondary, this research was conducted on pre-selected global sites, and compared country pages which are based in Australia, UK, Korea and Japan. The research questions were "what are design characteristics in different country web sites?" and "what are popular design features in Western and Eastern country sites?". The study attempted to find out the characteristics of design features. For the second research question, observations were conducted to determine the different design categories in four different countries. The author then investigated design features, where some design effects were taken into consideration, such as color, images, menu layout, etc. The data collection and research methods are similar to many studies, where exploratory research method is used to examine the web design of sites (Huberman, 1994; Jarvenpaa et al., 1999). This approach was found to be beneficial to confirm generalizations made in relation to test the impact of cultural differences on web design. This research is then used to formulate more precisely objectives for the final stage of the research.

\section{Investigation Design Categories}

Taxonomy of design feature categories is important in facilitating research in a systematic and meaningful fashion (see Table 2). The taxonomy presented in table 2 is based on leading 
researchers in HCI and E-commerce (Horton, 2006; John et al., 2000; Lazar, 2006; Nielsen, 2000; Norman, 2004) and used to categories observed features in global airline sites.

\begin{tabular}{|l|l|l|}
\hline & Categories & Details \\
\hline \multirow{5}{*}{ Design feature } & Page structure & $\begin{array}{l}\text { Linear, hierarchical, network or multiple } \\
\text { access links to product info }\end{array}$ \\
\cline { 2 - 3 } & Menu frame & Horizontal, vertical, or both \\
\cline { 2 - 3 } & \multirow{5}{*}{ Image } & $\begin{array}{l}\text { Image map, cartoon, moving or } \\
\text { stationary, country logo, or picture with } \\
\text { person/people }\end{array}$ \\
\cline { 2 - 3 } & Density of text & Low, medium or large on the home page \\
\cline { 2 - 3 } & High tech feature & Number, size, location \\
\cline { 2 - 3 } & Content & News, search or links for promotion \\
\cline { 2 - 3 } & Form & Search engine, booking from \\
\cline { 2 - 3 } & Global Links & Country, language options, \\
\hline $\begin{array}{l}\text { Information } \\
\text { presentation }\end{array}$ & Style of presentation & $\begin{array}{l}\text { Introduction, tailored information in } \\
\text { different countries }\end{array}$ \\
\hline
\end{tabular}

Table 2. Categories of design feature and information presentation

These issues are then investigated through different country sites in as many culture groups as relevant for the study, in this case two - Eastern and Western. The purpose of this investigation was to find the design characteristics and information presentation styles that are distinct to a culture. An exploratory approach is then taken to examine multi-linguistic sites. This enables understanding of typical design styles in different language sites.

The global airline sites presented in this example were observed in relation to web design features and target users. Common and popular features on all sites were identified and classified after which four countries' airline sites were selected for further detailed comparisons, two each in different country sites based in USA, Australia, Japan and Korea (South). The design features within the same airline site were examined for the purpose of comparing culture differences.

Twenty-four airlines were selected for the sake of this example to identify the common elements of web design features, and the airline sites examined were based in twelve countries. Only the home country sites were used for this portion of the study, which helped in forming an idea of common web design features in these sites.

\section{Findings}

Research findings are then summarised into the headings of design characteristics and comparative features. These are described in a greater detail in the following two subsections.

\subsection{Design Characteristics in Global SitesLanguage, Style Spelling}

From the investigation for the airline sites' example, hierarchical structure was found to be the most popular information layout for the airline sites. A flat hierarchy of information presentation structure is important for a successful web site design because it facilitates user 
understanding. It was apparent that airline sites considered user control in design and navigation features suitable for local sites and extended similar facilities to their global sites. Most sites observed in the study provided menu at the top and second levels in a hierarchical information format, following the hierarchy for a selected product group and brought up to the index or a text box for the search engine. Also the horizontal layout was observed to be the most popular form. Most of sites had top-down and left to right arrangement for the menu layout.

Images on airline sites were not a major feature of the site and mainly contained stationary images. Most of the sites contained more than three images per page. Cartoons and moving images were not popular, and only one airline site (Japan Airline) had some cartoon images on the site. All the sites in the study also contained the business logo except one site, and were mainly located on the top-left corner of the cover page. Some of sites had more prominent use of images such as on Eastern country sites, where images of people and big welcome signs were used to promote friendliness.

It was also confirmed that attractive features such as animations, video clips, or graphics may attract user's eyes, but static information on the web provides much easier comprehension and navigation. This investigation confirmed that the global sites were providing easy to look at images on the sites that promoted comprehension. However, the size of images was different in some country's sites and is described in more detail later in the chapter.

The prominent colors on airline sites were found to be 'blue' images on a 'white' background. The text density was also very high, with 'black' text delivering information mainly through functional form and menu. Generally, each site contained between three to five different colors for each site including text and images.

Unlike other popular e-commerce sites, none of the airline sites used pop up windows. Some sites contained rollover features, and many sites had moving images. Most sites did not provide multiple access links for product information, and same page features for other country's pages on the main home page. Some of the sites had the same design with different colors and pictures for other countries, but the theme color and images were the same as the home page providing an image of consistency. Though, some Eastern country sites did not follow this norm. They also generally had more moving images and bigger pictures than Western country sites.

Fourteen airline sites provided global sites through links. Furthermore, around 10 sites had different design features as on the home sites. Only 8 airline sites had different design pages for different countries as compared to the home site. Rest of the airline sites presented cover pages with different photos or menu frames as on the main home site, with the same information contents as the main home page. Over 14 sites had different page designs for different country sites, but presented the same type of cover pages with links to other languages/countries as the main home site. Thirteen sites provided different menu frame and colors on local pages.

From the twenty-four airline sites researched, most of airline sites provided English sites only, and they focused on English speaking users, mainly based in the USA. As for providing global links and sites for users from other countries, almost all airlines provided links to other country or regional sites, and only one business provided local sites for different countries. In fact, many global sites provided links to multilingual sites or other 
country sites from the main page. Most of the airline sites presented information in English on the cover page, except sites for Dutch, Japanese and Chinese airlines. Some country sites focused only on local users rather than other country users and provided local language on the cover page.

Most of airline sites required a user login facility to access service features, and the login form was located on the top of the sites. All airline sites provided multiple text boxes and drop-down selections for the booking forms. Mainly, these forms were located in the middle of the page. The popular design features of global airline sites in terms of position of the menu which is located on the top layout of the main sections for information presentation, which is oriented vertically; login located under the menu; form located in the middle of the page.

\subsection{Comparisons}

This section summarises the comparisons of different websites for the airline web sites' example. Table 3 shows in summary, the categories of design features clustered in selected groups of home page, and country pages in Korea (South)/Japan and Australia/UK. There are many design features that are different for other country sites for the same airline such as image links, overlapped images, number of persons in the picture, dominant page/text color and high-tech features. 


\begin{tabular}{|c|c|c|c|}
\hline Categories & Airline Home page & $\begin{array}{l}\text { Country pages directed } \\
\text { for Korean/ Japan }\end{array}$ & $\begin{array}{l}\text { Country pages } \\
\text { directed for } \\
\text { Australia/UK }\end{array}$ \\
\hline Image & $\begin{array}{l}\text { Image links are } \\
\text { popular but no } \\
\text { cartoon images. }\end{array}$ & $\begin{array}{l}\text { Business organisation } \\
\text { logo and images are } \\
\text { large. Mostly, the human } \\
\text { and female faces on the } \\
\text { picture. Many images } \\
\text { with links }\end{array}$ & $\begin{array}{l}\text { Smaller images are } \\
\text { popular }\end{array}$ \\
\hline Color & $\begin{array}{l}\text { Dominant color is } \\
\text { blue in text and } \\
\text { image. More than } \\
\text { three colors of text }\end{array}$ & $\begin{array}{l}\text { Multiple colored images, } \\
\text { text and backgrounds }\end{array}$ & $\begin{array}{l}\text { Use limited numbers } \\
\text { of color for text and } \\
\text { images }\end{array}$ \\
\hline $\begin{array}{l}\text { Density of } \\
\text { text }\end{array}$ & $\begin{array}{l}\text { Mainly with text } \\
\text { information on the } \\
\text { page }\end{array}$ & $\begin{array}{l}\text { Less text than the home } \\
\text { page }\end{array}$ & $\begin{array}{l}\text { Less text than the } \\
\text { home page }\end{array}$ \\
\hline $\begin{array}{l}\text { High tech } \\
\text { feature }\end{array}$ & $\begin{array}{l}\text { More rollover } \\
\text { features and search } \\
\text { tools available than } \\
\text { other country sites }\end{array}$ & $\begin{array}{l}\text { Pop up windows and } \\
\text { rollover features are } \\
\text { popular. The animations } \\
\text { are larger and located in } \\
\text { the middle or top. The } \\
\text { animations are mainly for } \\
\text { other businesses' } \\
\text { advertisements }\end{array}$ & $\begin{array}{l}\text { Moving images and } \\
\text { animations are } \\
\text { uncommon, and } \\
\text { usually located on } \\
\text { the right corner and } \\
\text { small }\end{array}$ \\
\hline $\begin{array}{l}\text { Particular } \\
\text { feature }\end{array}$ & $\begin{array}{l}\text { High density text on } \\
\text { the page }\end{array}$ & $\begin{array}{l}\text { The black text color is } \\
\text { common }\end{array}$ & $\begin{array}{l}\text { The animation is } \\
\text { small and own } \\
\text { business } \\
\text { organisation's } \\
\text { advertisement }\end{array}$ \\
\hline $\begin{array}{l}\text { Common } \\
\text { feature }\end{array}$ & \multicolumn{3}{|c|}{$\begin{array}{l}\text { Business organisation logo was the strongest image on the cover page. } \\
\text { Overall, blue color was commonly used. Multiple frames are in vogue. }\end{array}$} \\
\hline
\end{tabular}

Table 3. Characteristics of design feature in Western and Eastern county

From analysis, it seems designers for airline sites have different impressions of target markets, and tended to provide less text and more images. Designers often provided similar structure and design features on other country sites as home pages. All airline home sites 
provided search tools and links for finding more information. Particularly, Korean (South)/Japanese sites provided more than two languages including "Native" English and their own language for home sites. Most of the Korean (South)/Japanese sites provided alternative designs for local users. However Australian/ UK site rarely provided alternative design features (e.g. menu bar, multiple links, inter-linkages, etc), other than those on their home site. It was also observed that use of text, images, color and new high tech features in design for Korean (South)/Japan and Australian/UK sites were distinctly different. Australian/UK users were considered as equal to "Native" English site users on the Korean (South)/Japanese home site. Some Korean (South)/Japanese sites provided different designs for "Native" English and "non-Native" English users, and also provided different favourites for different language background users.

A typical page structure for Western country sites provided menu on the top and bottom, and main sections located in the middle of page. The pictures on the page are simple and not more than two were used. On the other hand, Eastern country sites show multi-layers of menu on the top and several pictures spread out in the main sections. The Eastern sites also tended to provide video clips, news and promotional links.

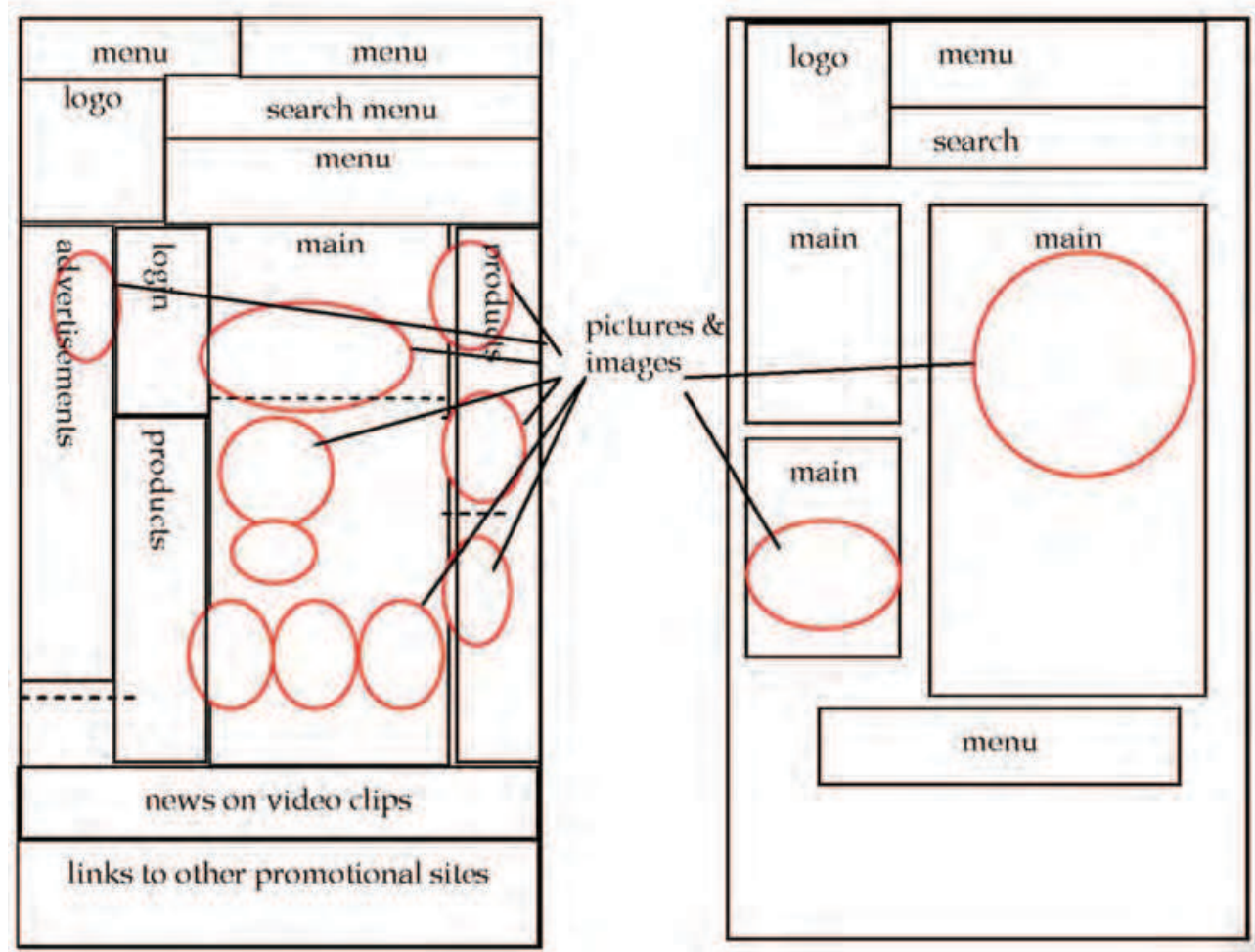

Fig 1. Popular design features in global sites: East (left) vs. West 
The Western sites usually had an introduction page, which provided information about the business organisation, its market and then the product information could be accessed through links on the main page. In comparison Korean (South)/Japanese sites provided no introduction and took the user directly to links for selection of services and products. By looking at different design features, there was a clear connection between design features and pages aimed at or originating from certain cultures.

\section{Summary and Conclusion}

The investigation on airline sites based in Eastern and Western country confirms that there are certain ways to localise web sites based on cultural differences of target users. These suggestions were made to plan ahead, as all languages are not created equal and have their own nuances. The suggestions encourage a designer to be aware of cultural differences, present a clear choice, know the target users, avoid slang, and keep information current on the site. However not many airline sites seemed to be aware of how cultural difference impact on local users' preferences. Even though a global site provided links to other country sites, the site was in English and only three sites provided languages other than English for other country users. However the investigation provides an important framework for evaluating characteristics of web design features, and identifying culture differences that will help improve ease of use and satisfaction for international users. It was observed during the study that global airline sites mainly focused on English users rather than on other language users. In general, global e-commerce sites provided links to regions or country pages, which were partially customised. The customisation goes some way in providing access to international users. This convenience does break a language barrier but most of the global sites only provided essentially the same design features as on the home page. Perhaps this common practice aligns with providers' business goals or other reasons for creating awareness amongst customers, but does not deliver the full potential of a B2C ecommerce business. However it is necessary to understand users in different countries and their experiences in global sites to be effectively involved with e-commerce because customers are more comfortable with doing business in a familiar environment. This implies that, it is necessary to elicit how the web design features appeal to users in different cultures, and how designers in different countries approach the creation of usable design features for local and international users.

The investigation was targeted on finding commonalities and differences in design features related to different countries based on global airline sites. The reason for studying global airline sites was that airlines provide similar services following similar business practices, so the design features were more likely to be linked to target users' and designers' country of origin and typical choices of preferred web design features. The fact that airlines provide global services, covering multiple cultural groups also makes it logical to derive such conclusions. The key conclusion of this investigation was that the different country users have different favourites and reasons to use global sites. Hence the e-commerce providers and designers need to be prepared to make a distinction in design of sites for international users. It is important that the international users have different ways of adopting culture in e-commerce especially in a global context. In global sites, adopting culture in e-commerce 
will accelerate creation of a new form of design of sites for international users which would address customers' concerns placed in a particular cultural setting.

\section{References}

Afuah, A., \& Tucci, C. (2003) Internet Business Models and Strategies (2nd ed.). New York: McGraw-Hill.

Badre, A. N. (2002) Shaping Web Usability: Interaction Design in Context. MA, USA: Pearson Education Corporate.

Barber, W., \& Badre, A. (2000) Culturability: The Merging of Culture and Usability. Florham

Park, NJ: AT\&T research centre. Callahan, E. (2008) Cultural differences in the design of human-computer interfaces: A multinational study of university websites, Humanities and Social Sciences (Vol. 68):

PsycINFO Database.

Chau, P., Cole, M., Massey, A., Montoya-Weiss, M., \& O'Keefe, R. M. (2002) Cultural

Differences in the online behaviour consumers. Communications of the ACM 45(10),138143.

Chen, L., Gillenson, M. L., \& Sherrell, D. L. (2004) Consumer Acceptance of Virtual Stores: A Theoretical Model and Critical Success Factors for Virtual Store (Vol. 5): ACM SIGMIS.

del Galdo, E., \& Nielsen, J. (1996) International User Interface. USA: Katherine Schowalter.

Elliot, S., \& Keen, P. (2002) Electronic Commerce: B2C Strategies and Models. UK: Wiley.

Fernandes, T. (1995) Introduction to Culture: Global Interface Design. UK: Academic Press.

Ford, G., \& Gelderblm, H. (2003) The effects of culture on performance achieved through the use of human computer interaction. Paper presented at the the 2003 annual research conference of the South African institute of computer scientists and information technologists on Enablement through technology (SAICSIT '03), South African.

Gefen, D., \& Devine, P. (2001) Customer loyalty to an online store: the meaning of online service quality. Paper presented at the Twenty Second International Conference on Information Systems (ICIS), Louisiana, USA.

Horton, S. (2006) Access by Design-A guide to universal usability for web designers. USA: New Riders.

Huberman, I. M. a. A. M. (1994) An expanded Sourcebook Qualitative Data Analysis (2nd ed.). CA: Sage.

Internetworldstats. (2007) Top Ten Languages Used in the Web, Internet World Users by Language: MiniWatts Marketing group, www.internetworldstats.com, viewed on 25th Mar 2008.

Jarvenpaa, S. L., Tractinsky, N., \& Vitale, M. (1999) Customer Trust in an Internet Store: A Cross-Cultural Validation. Journal of Consumer Marketing Commerce 5, 1-30.

John, S., Wilkens, M., Morris, P., \& Masera, M. (2000) Trust requirements in E-business. Communication of ACM 43(12), 81-87.

Kang, K. S., \& Corbitt, B. (2002) Effectiveness of Graphical Components in Web Site Ecommerce Application-A Cultural Perspective. Electronic Journal of Information Systems in Developing Countries 7.

Kim, J., \& Moon, J. Y. (1998) Designing towards emotion useability in customer interface: Trust worthiness of cyber banking system interfaces. Interacting with Computer 10,1-29.

Lazar, J. (2006) Web usability : a user-centered design approach. Boston: Pearson Addison Wesley. 
Nguyen, L., Torlina, L., Peszynski, K., \& Corbitt, B. (2006) Power relations in virtual communities: An ethnographic study. Electronic Commerce Research-Special Issue on Virtual Communities in E-Commerce 6(1), 21-37.

Nielsen, J. (2000) Designing Web Usability. USA: New Riders Press.

Norman, D. A. (2004) Emotional design: why we love (or hate) everyday things. New York: Basic Books.

Piller, I. (2003) Advertising as a site of language contact. Anual Review of Allied Linguistics 23, 170-183.

Rose, G., Evaristo, R., \& Straub, D. (2003) Culture and consumer responses to web download time: a four-continent study of mono and polychronism. IEEE Transaction on Engineering Management 50(1), 31-44.

Shneiderman, B. (2000) Universal Usability. Communications of the ACM 43, 85-91.

Statistics, A. B. S. (2007) 2006 Census QuickStats : Australia. Canberra: http://www.abs.gov.au/Ausstats/ (viewed on 15th Oct 2007).

Sudweeks, F., \& Ess, D. (1998) International Cultural Attitudes Towards Technology. Paper presented at the International Cultural Attitudes Towards Technology and CommunicationCaTac'98.

Timmers, P. (1998) Business Models for Electronic markets. Journal of Electronic Markets 8(2), 3-8.

Timmers, P. (2000) Electronic Commerce: Strategies and Models for Business-To-Business Trading. England: John Wiley \& Sons Ltd. Yin, R. K. (1994) Case study research: Design and methods. California: Thousand Oaks, Sage. Zhang, P. a. v. D., G M. (2000) Satisfier and Dissatisfier: A Tow-factor Model for Website

Design and Evaluation. Journal for Inforamtion Science of the American Society 52(14),1253-1268. 


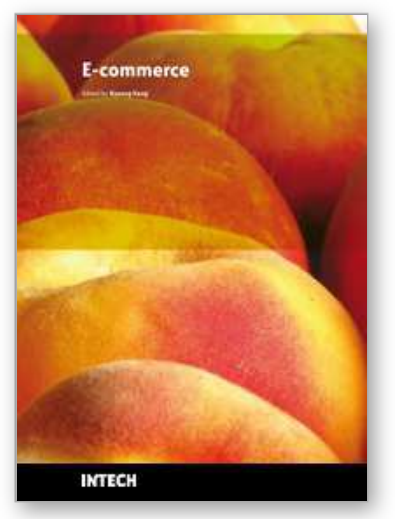

\author{
E-commerce \\ Edited by Kyeong Kang
}

ISBN 978-953-7619-98-5

Hard cover, 284 pages

Publisher InTech

Published online 01, February, 2010

Published in print edition February, 2010

E-commerce provides immense capability for connectivity through buying and selling activities all over the world. During the last two decades new concepts of business have evolved due to popularity of the Internet, providing new business opportunities for commercial organisations and they are being further influenced by user activities of newer applications of the Internet. Business transactions are made possible through a combination of secure data processing, networking technologies and interactivity functions. Business models are also subjected to continuous external forces of technological evolution, innovative solutions derived through competition, creation of legal boundaries through legislation and social change. The main purpose of this book is to provide the reader with a familiarity of the web based e-commerce environment and position them to deal confidently with a competitive global business environment. The book contains a numbers of case studies providing the reader with different perspectives in interface design, technology usage, quality measurement and performance aspects of developing web-based e-commerce.

\title{
How to reference
}

In order to correctly reference this scholarly work, feel free to copy and paste the following:

Kyeong Kang (2010). Considering Culture in Designing Web Based E-commerce, E-commerce, Kyeong Kang (Ed.), ISBN: 978-953-7619-98-5, InTech, Available from: http://www.intechopen.com/books/ecommerce/considering-culture-in-designing-web-based-e-commerce

\section{INTECH}

open science | open minds

\section{InTech Europe}

University Campus STeP Ri

Slavka Krautzeka 83/A

51000 Rijeka, Croatia

Phone: +385 (51) 770447

Fax: +385 (51) 686166

www.intechopen.com

\section{InTech China}

Unit 405, Office Block, Hotel Equatorial Shanghai

No.65, Yan An Road (West), Shanghai, 200040, China

中国上海市延安西路65号上海国际贵都大饭店办公楼 405 单元

Phone: +86-21-62489820

Fax: $+86-21-62489821$ 
(C) 2010 The Author(s). Licensee IntechOpen. This chapter is distributed under the terms of the Creative Commons Attribution-NonCommercialShareAlike-3.0 License, which permits use, distribution and reproduction for non-commercial purposes, provided the original is properly cited and derivative works building on this content are distributed under the same license. 